\title{
DÜBLIN
}

Technological University Dublin

ARROW@TU Dublin

\section{Heritage sites and schoolchildren: insights from the Battle of the Boyne}

\author{
Dervilia Roche \\ Technological University Dublin \\ Bernadette Quinn \\ Technological University Dublin, bernadette.quinn@tudublin.ie
}

Follow this and additional works at: https://arrow.tudublin.ie/tfschhmtart

Part of the Other Education Commons, and the Social and Behavioral Sciences Commons

\begin{abstract}
Recommended Citation
Roche, D. \& Quinn, B. (2016) Heritage sites and schoolchildren: insights from the Battle of the Boyne, Journal of Heritage Tourism, published online June 2016. doi:10.1080/1743873X.2016.1201086
\end{abstract}

This Article is brought to you for free and open access by the School of Tourism \& Hospitality Management at ARROW@TU Dublin. It has been accepted for inclusion in Articles by an authorized administrator of ARROW@TU Dublin. For more information, please contact arrow.admin@tudublin.ie, aisling.coyne@tudublin.ie, gerard.connolly@tudublin.ie.

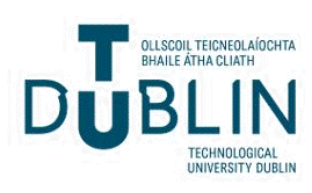


HERITAGE SITES AND SCHOOL CHILDREN: INSIGHTS FROM THE BATTLE OF THE

BOYNE, published in the Journal of Heritage Tourism DOI: DOI:10.1080/1743873X.2016.1201086

\section{Dervilia Roche and Bernadette Quinn}

\section{Author Biographical details}

1. Dervilia Roche completed an MSc Tourism Management at the Dublin Institute of Technology where she completed a study on how children make sense of heritage sites. She has recently worked in the National Museum of Ireland and for the Office of Public Works heritage services. [Dervilia Roche, Broomfield, Collon, Co. Meath [roched1@tcd.ie; +353 863745654]

2. Dr. Bernadette Quinn* is a geographer whose research interests include festivals and cultural tourism. Her work has been published in such journals as Annals of Tourism Research and Journal of Sustainable Tourism. Her address and the affiliation where the research was conducted is: Department of Tourism, Dublin Institute of Technology, Dublin 1, Ireland. [Bernadette.quinn@ dit.ie; Tel: 00353 (0)1 4027557]

*corresponding author

Disclosure Statement: This research is non-funded. 


\title{
HERITAGE SITES AND SCHOOL CHILDREN: INSIGHTS FROM THE BATTLE OF THE BOYNE
}

\begin{abstract}
Children are very much under-represented in heritage tourism studies, particularly in terms of their own perspectives. This exploratory study begins to redress this imbalance by investigating how 34 primary school-going children experience and make sense of the Battle of the Boyne Visitor Centre, an Irish heritage site. Among the research questions posed are: how does the group make sense of heritage? Where do they get their ideas about heritage attractions? What appeals to them about heritage attractions? The research adopted an interpretivist approach and employed a variety of innovative data collection tools, gathering ideas from the children through discussions, writing, drawings and observations, both in their classroom and on a heritage site visit.

The findings pointed to how the children's preconceptions of a heritage site are informed by their perceptions of the location, and images formed from television. Their enjoyment of a site was found to be relative to their enjoyment of other places that they have visited. The findings also indicated the importance of interaction with media, technology and visuals. Finally, the study indicated the importance of social interaction, both with their peers and their Tour Guide. A number of policy implications are drawn.
\end{abstract}

Keywords: Children, Heritage sites, Heritage interpretation, Meanings, Ireland 


\section{INTRODUCTION}

Just as in the tourism domain, children are very much under-represented in heritage studies. The gap in the tourism literature has already been noted by Graburn (1983) and more recently by Small (2008) and Poria and Timothy (2014). Very recently, this gap is beginning to be addressed (Carr, 2011; Kerr and Price, 2016; Schanzel, Yeoman and Backer, 2012), but until this point, on the few occasions when children were addressed, it was usually commercial or marketing questions that were at issue. Often the interest lay in determining the influence that children exert on adults' decision-making processes (Madrigal, 1993; Thornton, Shaw and Williams, 1997; Wang, Hsieh, Yeh and Tsai, 2004). Likewise, studies in family tourism tend to be concerned with adults' perspectives (Obrador, 2012) rather than children's. The invisibility of children in the related field of heritage studies seems equally noteworthy but as yet has received relatively little commentary in the literature (e.g. Kerr and Price, 2016). While a sizeable literature attends to the nature of the heritage tourist and covers a wide range of topics including motivation, perceptions, and behaviour, the subjects studied are invariably adults (Poria, Butler and Airey, 2003). As in the more general tourism literature, children in heritage have tended to be considered in so far as they have an influence on the behaviour of adults in terms of, e.g. making a decision to visit an attraction, and deciding what activities to undertake while there (Wang et al, 2004).

This paper begins to redress this imbalance by investigating how a group of 11-12 year old children experience and make sense of a school trip to a heritage site that functions as a visitor attraction. This exploratory research serves to outline some of the ways in which children make sense of heritage sites and paves the way for further research on the subject. The perspective adopted is not commercial or marketing in orientation although the findings of the research have application of this nature. Rather, the intention is first and foremost to draw attention to the fact that children represent a sizeable and distinct component of visitor flows to many heritage attractions and as such, merit research attention for a wide variety of reasons. Tilden (2007) argued that heritage interpretation for children must not be a diluted version of that for adults but rather something completely different. The need to understand children not just as future adults but as people in their own right has also been noted by Black (2001) and Tabraham (2006). The research presented follows this line of argument and asks a number of research questions including: Where do children get their ideas about heritage attractions? What appeals to them about heritage attractions? What impression does the experience of visiting heritage attractions make on them? Theoretically, the paper reviews literature on people's and particularly children's experiences of heritage sites. The empirical setting for the research is a battlefield heritage site. Battlefields have received growing attention of late (Dunkley, Morgan \& Westwood, 2011; Frost \& Laing, 2013; Ryan, 2007) and interpretation of battlefield conflicts is of increasing interest to tourism researchers. To date, little attention 
has focused on children as visitors to such sites. This paper reports the findings of research undertaken to investigate how 34 school-going children aged 11-12 years old experience and make sense of a statemanaged battlefield heritage site in Ireland while on a school trip. The research adopted an interpretivist approach and employed a variety of innovative data collection tools, gathering ideas from the children through discussions, writing, drawings and observations.

\section{MAKING SENSE OF HERITAGE SITES}

The extensive body of literature dealing with heritage sites seems to concur that experiences of heritage are strongly predicated on personal influences. An artefact, site or event can have different meanings for different people depending on how the heritage is viewed or understood, or on what expectations are placed upon it. Poria et al (2003), for example, concluded that heritage exists not because experts claim it but rather because it is meaningful for the individual(s). They found that when visitors perceived a site as being part of their own heritage they felt more emotionally involved and more satisfied with their visit to the site. Burnett (2001) similarly argued that when people experience heritage sites they reassess their lives and their past in a way that makes the heritage experience a time for personal engagement and reflection. The realization that understandings of heritage are complex, multi-faceted and individualistic centrally informs the enormously important task of heritage interpretation. Much has been written about heritage interpretation. According to Moscardo (1996), its purpose is to enhance the experience of visitors and to make them more aware of heritage, its associated history and the current issues surrounding it. Tilden (2007), whose work in the field of interpretation has been seminal, explained its role in terms of provocation as opposed to instruction, and as an endeavor that aims to cause visitors to experience a revelation. Both Moscardo (1996) and Tilden (2007) conceptualize the aim of interpretation as being the connection of the heritage at issue with the personality of the visitor.

In recent years, a key development in heritage interpretation has been the introduction of technology in various guises to enhance the dynamism, interactivity and multi-sensorial nature of the interpretation. This development acknowledges that visitors understand and experience heritage not only through their 'gaze' (Urry, 1990) but also on a sensory, emotive and embodied level (Schorch, 2012). It also attests to Moscardo's (1996) ideas about 'mindful' and 'mindless' visitors. The former are openminded, inquisitive and receptive while the latter tend to be generally less concerned with the exhibitions and interpretation on offer. In order to entice the 'mindless' visitor to engage and to have a more satisfying experience, it is argued that heritage attractions should offer interpretation that provides both variety and 
control to the visitor (Moscardo, 1996). A number of researchers have concluded that interactive, multisensorial interpretation is more educational and more enjoyable than other types. Durbin's (2002) research found that the use of multimedia (e.g. audio visuals, videos, interactive computer displays, objects to touch, music as well as 'hands on' activities such as making things) both increases the amount of time that visitors spend at an exhibit and their understanding of the exhibit on display. Elsewhere, Kelly's (2000) research found that visitors were most attentive when live displays were employed and that interactive displays were considered to be most successful amongst all visitor groups.

\subsection{Children and heritage}

While this research focuses on a school group of 11-12 year olds, the literature on children's perspectives of heritage sites remains so sparse that it has been necessary to consult sources which focus on a variety of age groups and types of group within childhood/adolescence. However, despite this variety, there are a number of recurring themes in respect of visitor behaviour issues. There seems, in the first instance, to be a general consensus about the need to offer children opportunities for active, experiential forms of engagement with heritage. Kelly's (2000) finding in respect of the successfulness of interactive displays, for example, was particularly emphasized in the case of children. Elsewhere, Nickerson and Jurowski's (2001) study stressed the importance of activities in generating a fun experience, which contrasts with the more general literature on heritage focusing on the need for revelation and reflection (Burnett, 2001; Tilden, 2007). Writing about interpretation, Tilden (2007) noted the need to accommodate children's fast rate of learning and their highly receptive minds which are generally clear of the personal or social issues that can burden adult minds. He implied that it should be relatively easier to hold children's attention although he acknowledged that developing interpretation for children introduces some difficulties. These include the fact that children tend to notice small details in a way that adults may not; that interpretation for children must help them relate to remote concepts /objects (by, for example, explaining difficult words); and that efforts must be made to enable children to identify with the historical scene or to live the historical experience in question. Meeting these needs requires interactivity, as discussed in Black (2001) where children's interest in touching items, dressing up, participating in computer-based activities, competitions, trails, etc. was noted.

Specifically in terms of school children and their experiences of heritage sites, there is a lack of previous research. The importance of school tourism as an emerging strand of tourism is outlined by Ritchie, Carr and Cooper (2003). They note that this is a strand of educational tourism, and that trends in education and travel are set to see the market grow rather than contract. Their research focuses mainly on school tourism from a supply side, noting that educational provision in many European museums has 
improved in recent years, with a greater emphasis on technology and imagination, creating an experience for school children which is both entertaining as well as educational (Ritchie et al, 2003). However, the views of school participants on school trips have only rarely been studied (Ritchie et al, 2003). Larsen and Jenssen (2004) presented a study of reasons and motivations for 14-15 year olds going on a school trip. The importance of social interaction with peers was identified here, and reoccurs throughout other literature. Larsen and Jenssen (2004) found that children were mainly motivated by social reasons and the need for social belonging. For them, the social aspect of being with others was more important than any other dimension of the trip. With regards to school children's perspectives of heritage site visits, the gap in previous literature is even greater.

Both of Larsen and Jenssen's (2004) findings: the need for active, experiential engagement; and the need for social belonging echo findings in Small's (2008) tourism research. She explored memories of childhood holidays and found that the most positive memories involved shared, fun, physical activities and sensory experiences where children were absorbed, especially in the company of other children. Likewise Schanzel (2012) confirmed that holidays for children have a stronger social dimension than those for adults. The nature of the social interaction between the heritage Guide and children visiting heritage attractions is a further point raised by Tilden (2007). He argued that Guides should conceal direct instruction and instead create a relaxed learning environment which clearly sets the heritage site apart from the classroom. In the process, they should create a sense of companionship with the children. Dahles (2002) refers to research by Cohen which conveys that a Guide must translate the strangeness of a foreign culture into something familiar to the visitors. This may be even more important for younger visitors who may arguably have less previous knowledge of the subject than adult visitors. In related fashion, Durbin (2002) wrote about the importance of social interaction between adults and children during visits to heritage attractions and of the need for exhibitions to generate conversation between them.

In some respects, the importance of the social dimension apparent here relates to the importance of play in young people's lives. Kadlec (2009) wrote about the importance of play in enabling children to learn the benefits of trust, problem-solving, fairness, etc. She argued that children combine the reality around them with imagination (e.g. creating narratives in their mind). The well-understood relationship between play and learning is underscored here and clearly, when children constitute the visitor group, the educational potential held by many heritage attractions becomes paramount. In order to realize this potential, the incorporation of playfulness into interpretation at relevant heritage sites seems wise, as the inclusion of stimuli for the imagination, as well as the freedom and scope for children to withdraw into the part-fantasy, part-reality world of heritage could enhance the learning experience. Central to the learning environment, researchers concur, is plenty of opportunity for 'hands-on' experiences (Tilden, 2007; 
Wendling, 1989). Munday (2002) argued that children should be allowed direct contact with the historical objects themselves, suggesting that the benefits of learning from direct handling e.g. learning how objects feel and weigh and experiencing their finer details outweigh any risk of loss or damage to the objects.

In terms of trying to understand how children approach heritage, existing literature seems to suggest the need to begin by examining how children view the world more broadly. It also highlights the importance of existing knowledge in children's negotiations of 'newness' more generally. Researching children's attitudes to holidaying overseas, for example, Cullingford (1995) found that children tended to find the countries that were culturally familiar to be most attractive as holiday destinations. Cultural familiarity was often mediated by television. More generally, he noted that children tend to enjoy things and activities (e.g. certain foods) that were familiar with their routine home lifestyles. The importance of familiarity, or of what is personally known, recurs in Barca and Pinto's (2005) research on how children make sense of historic streets. They argued that the nature of children's historical understanding has three dimensions. Children firstly understand observed features in the light of personal experience. In this case it was found that children's perceptions of the past had been transmitted by books, teachers, elderly people, as well as in contemporary images and television. Secondly, understanding comes from a combination of personal experience and restricted historical belief (drawn from school, community and personal experience). The third dimension of children's understanding is creative and reflective in nature. According to Barca and Pinto (2005) it involves children questioning conventional wisdom, putting forward their own views on what should be valued and how affairs should be managed.

The literature on children and heritage has also adopted a more pragmatic tone in noting some of the practical implications that attend accommodating children as visitors to heritage sites. Black (2001), for example, listed some of the challenges involved. Among these he cited the need to: avoid broken or poorly functioning elements within an exhibition as these may evoke quick frustration in children; design exhibitions that can 'withstand hammering' by children and; cater to the needs of children of differing ages and to families with siblings of differing ages. Durbin (2002) took up this theme, noting that children enjoy discovering things and so should be able to 'open up' parts within the exhibition.

Overall, however, what appears to be missing from the literature is an emphasis on understanding how children themselves experience and understand heritage and perceive heritage attractions. This seems to undermine existing international and national policy interest in advancing young people's access to culture. Internationally, the 1989 Convention on the Rights of the Child is very clear that children have the right to participate fully in cultural and artistic life. UNESCO reinforces this view in its supports and initiatives to promote world heritage education for young people (WHC, UNESCO 2010). At the EU 
level, the importance of young people's access to culture is addressed in the 2008 European Commission document. In Britain a number of diverse policy documents address the issue of children and heritage. The British Kids in Museums Manifesto, for example, offers guidelines on how to make museums accessible for children, suggesting, for example, that space must be provided to accommodate the needs of different age groups (e.g. for toddlers to let off steam, or for teenagers to 'hang out'). In another heritage sector, the National Trust has a well operationalized policy of access for children with a wide range of events for families, opportunities for discovery and learning aimed at different age groups, an interactive games section on its website and a cartoon character called 'Trusty' who, like UNESCO's character 'Patrimonio' is designed to make children more aware of the importance of heritage sites (Taylor, 2006).

\section{STUDY METHODS}

This study was approached from an interpretivist point of view, aiming to determine how a group of children made sense of a heritage attraction, and investigating the feelings and attitudes of the children. There were a number of data collection phases between 28th March and 9th June 2011 by one researcher. At the outset, two in-depth semi-structured interviews were conducted with Education Officers at the National Museum of Ireland and the National Gallery of Ireland, two important national cultural institutions. This was intended to explore the subject of children and heritage from suppliers' points of view and generated a set of initial ideas which fed into the design of subsequent phases. The main data collection was undertaken in three phases, over three days, both in a school and on a school trip to a heritage site.

The importance of school tourism as an emerging strand of tourism is outlined by Ritchie et al (2003), and working with a group in their school had the added benefit of accessing a number of children at one time. Barker and Smith (2001) note that when children are in their day-to-day spaces, they are the experts and the researcher is the novice. As well as this, it was noted by Isaksen \& Roper (2010) that when working with children it is important to use a room where they are not distracted by their surroundings, so undertaking research in their classroom was appropriate for gathering data from the children. Being an exploratory study on children's perspectives on heritage sites, the main data collection focussed on one class group of 34 primary school children aged 11-12 years and one heritage site. As the topic of children and heritage sites is so understudied, it was felt that a study of any age group of children would add to existing knowledge on the topic. This particular age group was chosen for study because it was thought that they would be old enough to work cooperatively with a researcher and sufficiently articulate (both verbally and in writing) to communicate their views. 
The heritage site chosen for this study was the Battle of the Boyne Visitor Centre, located at Oldbridge, Co. Meath, the site of an important seventeenth-century battle. It was chosen due to its variety of media and interpretation methods, some of which are particularly novel, with an emphasis on visual and dynamic elements rather than on text. The interpretation includes an audio-visual display about the battle, much of which is presented in a dramatic movie-style, rather than the more traditional purely documentary style. There is also a laser display on a battle site model which explains the movements of the armies. As well as this, there are paintings, panels, maps, mannequins, videos, and weaponry. Further interpretation is offered by guided tours. The researchers identified a primary school group of 11-12 year olds who were planning on making a school trip to the Battle of the Boyne heritage site at a time period which was opportune for this study, and as such these were chosen for the study. While some of the group had previously visited the site in question, it was their first time visiting as a school group.

Phase 1: The initial data collection took place in the children's classroom and was designed to determine the children's prior knowledge, experiences and opinions. They were initially given hand-outs with images of heritage sites (both Irish and international, natural and cultural sites) and asked to write about whatever they thought of when they looked at them. MacAuley (1996) in previous research used visual stimuli to gain an insight into children's perceptions. This exercise was intended to 'break the ice', and the images were chosen so as to promote discussion on a variety of types of heritage sites. This was followed by a general discussion which was steered through four main subjects: heritage sites in general, the Battle of the Boyne Visitor Centre, previous school trips, and expectations of the next day's visit. Phase 2: The next day, at the Battle of the Boyne Visitor Centre, data were firstly gathered from observing the children on a guided tour of the exhibition. Following this, the children were given a quiz based on the exhibition. Finally, they were asked to either write about, or draw a picture of, their favourite part of the exhibition. Phase 3: Back in the school the following day discussions were held and recorded on: the previous day's trip; comparison of the previous day's trip with trips to other similar places or to places on holiday; and a comparison of the previous day's visit with any schoolwork they had done on the Battle of the Boyne.

Please insert Table 1 about here

Each group discussion lasted approximately 40 minutes, and involved dialogue that used simple language and open-ended questions in such a way as to encourage as much engagement as possible, and to motivate children to take the lead. Bundy (2005) indicated that group work with children is beneficial in how it encourages conversation and honesty, and avoids intimidation. The discussion sessions were comparable to focus group work, which Berg (2009) noted is an excellent means for collection 
information from children as it encourages them to speak freely. The phased data collection approach was found to work well in generating insights into the children's feelings and attitudes before, during, and after their heritage site experience. It was constructive in that data from each phase informed the preparation of subsequent phases. It also helped the researcher build trust with the children. This encouraged them to feel more at ease and to speak more freely. Saunders, Lewis \& Thornhill (2007) noted that interpretivism requires the researcher to enter into the social world of the subjects and see things from their points of view, and so the phased approach here allowed the researcher to develop a familiarity with the children over time, which aided the interpretation of the children's ideas.

At the end of three phases, the data gathered consisted of audio recordings of discussions in phase 1 and 3, observational notes from phase 1,2 and 3 (including some quotes from the children, some observations on their tone and body language, and notes on parts of the exhibition that they appeared to enjoy, be confused by, etc), handouts from phase 1 as completed by the children, and handouts with written pieces and drawings from phase 2 as completed by the children. While a small number of children did not participate as fully in the discussions as others, a large amount of data were gathered. In addition, written data and drawings were gathered from all 34 participants. The drawings proved useful in indicating what the children tended to visually note and remember from different parts of the visit. Using a variety of data collection tools allowed the children to communicate their ideas in different ways, thus ensuring the likelihood of the researcher understanding their ideas as fully as possible.

At the end of phase 3, all of the data were thematically analysed. This involved enumerating certain details (e.g. favourite parts of the visit) and identifying specific comments, written ideas, or elements of drawings which appeared to apply repeatedly, either to a large number of children in the class, or those which appeared several times through the three research phases. Then these specific answers were grouped according to more general, common themes. In the case of the written pieces and drawings of their favourite part of their visit, a simple count of which parts of the visit appeared most was also undertaken. As well as this, some initial analysis took place throughout the three days, similar to that mentioned above, allowing opportunities to clarify and further discuss certain ideas with the children.

\section{RESULTS}

\subsection{Perceptions of Heritage Sites in general}

The children's perceptions of the heritage sites presented to them by the researcher for discussion seemed 
shaped by a number of key influences. Early interviews with the two Education Officers had emphasised the extent to which children's views of heritage are as much affected by messages they receive externally (e.g. from parents, teachers) as by anything they encounter within the site itself. In phase one, this was confirmed, with the highly influential role played by television programmes and movies being particularly striking. An image of the Colosseum (Italy), for example, was associated with gladiators, which the children claimed they were familiar with from television. It elicited mentions of 'Romans, blood and sand, death'. The Grand Canyon (USA), meanwhile, generated responses including 'makes me think of cowboys'. A later discussion with a boy on the topic of flintlock muskets (a type of weapon used in the exhibition) revealed that 'there was a movie I saw called The Three Musketeers and that was in it'. As each of these quotes were discussed, many other children in the class agreed with the comments.

In addition, children's impressions of heritage sites were informed by their broader knowledge about the places where the sites were located. So, for example, the Pyramids (Egypt) were identified as 'a hot place'; the Colosseum encouraged one child to write ' I think of Italy. And then pizza'; the Eiffel Tower, according to one boy was 'supposed to be romantic', because it is in Paris. When questioned about why they thought of Paris as being romantic, many children responded again that they had learned this from television. The children's own personal associations with sites were also important to them. This involved both a tendency to imagine themselves at the site, for example one child for whom the image of the Eiffel Tower was a reminder of 'my fear of heights', as well as their tendency to think about the role certain sites already play in their lives, for example when discussing Newgrange, a World Heritage Site close to where they live, many of them commented on living near it or having visited it: 'I go there every year'.

\subsection{Experiences of Heritage Sites}

During the first data collection phase, children were asked about their previous class outings. A number of observations emerged from these discussions and were further supported in subsequent phases of the research. Most obviously, and not surprisingly, it was clear that the degree of activity associated with particular visits emerged as a strong factor shaping their memories. The class was in general agreement that their most preferred trip to date had been to an outdoor adventure park. Other comments supported the preference for activeness: one child, for example, said that a previous visit to an abbey had been better than a trip to the Battle of the Boyne site because they had been 'able to run around and climb a lot'. Equally, the interest in being active was evident in some of the children's comments on the hand-outs. One of them wrote: 'I'd love to try and climb on them' alongside an image of the Giant's Causeway, a World 
Heritage Site in Northern Ireland. Another factor that emerged in line with existing literature (Tilden, 2007) was the strongly influential role of the Tour Guide. Most of the class agreed that their least favourite school trip had been to a site where their Tour Guide was 'giving out' to them (scolding them) and 'seemed bored'. A third factor that emerged at this early stage of the research was the importance of social interaction. Several of the children were making a return trip to the Battle of the Boyne heritage site, but anticipated that the imminent school trip to the site would be better than their previous visits because this time they would be with their friends. However, when asked whether being with their friends was the most important thing on a school trip, some of the children disagreed and said 'I want to go somewhere fun' , interestingly placing importance on the choice of destination also.

Regarding what the children learned and remembered from their visit to the Battle of the Boyne site during phase 2, they tended to remember both things that their Tour Guide physically pointed out, such as 'the cannonball over the door', and the things the Guide described with gestures, for example, the musket loading drill. With regards to what parts of the visit the children enjoyed, a lot of the children agreed that 'pictures are better than reading' in exhibitions. However, while completing the quiz, the children needed to search for the answers in the exhibition, and it was apparent during this that they were excited when reading the information panels, suggesting that for most of the children, reading is more enjoyable when searching for specific answers. Indeed, they confirmed this when later asked about it. It was clear from both the writings and the drawings completed in phase 2 by the children that there were several parts of the exhibition which strongly appealed to them. An analysis of this data indicated that 15 of the children identified the audio-visual movie as their favourite part of the visit, and six others included it as one of their favourite parts of the visit. Some drawings of the audio-visual indicate a strong memory of the soldier's uniforms, including their hats and other aspects of their uniform. Several of the drawings of scenes from the audio-visual seemed to include humorous aspects, such as speech bubbles beside the soldiers.

Please insert Figure 1 about here

Two other parts of the exhibition were popular: the laser display and the weapons. The children had a strong visual memory of the laser display, with nearly every child colouring the lasers red and blue (as they are in reality), and drawing the positions of the lasers on the model relatively accurately. The children appeared to be interested in the technology involved in the audio-visual, as well as the content, and one drawing of the laser display even included the projector for the lasers. When discussing the laser display, the children tended to be enthusiastic about the fact that the model had been lit up by lasers, rather than what the lasers had actually been explaining. Following on from this, most of the children believed that 
the audio-visual explained the battle better than the laser display. When asked why, there were various responses, including: 'It shows everyone panicking, and how scary it is' and 'It kind of shows you how long it took to get the cannon ready'. Detailed aspects such as these appeared to interest them more than looking at the 'bigger picture' of the battle tactics which were shown in the laser display. Regarding the weapons, the children seemed to like imagining what it would have been like to be a soldier and use the weapons.

Please insert Figure 2 about here

While the children appeared to learn a lot from visiting (this could be grasped from a comparison of their ideas about the battle in phase one with phase three), even after visiting, some of their ideas were still those which had been developed previous to the visit. For example, one child spoke about one of the protagonists of the Battle of the Boyne being a 'coward'. This is something which is not mentioned in the exhibition, and it is likely then that this child may have held ideas from school/parents/other sources.

\subsection{Engaging with heritage -drawing on familiar and imaginary worlds}

An analysis of emergent themes sheds light on the various ways that children make sense of heritage, including where they get their ideas from, what appeals to them about heritage, and how heritage experiences make an impression on them. In terms of how they form their impressions of heritage sites, it seems clear that their already familiar worlds are very influential. The first phase of the research found a strong tendency for the children's perceptions to be rooted in television or movies, or in the associations they had already formed with a site's location, which in turn may also have been linked to television and movies. This relates to Cullingford's (1995) ideas of how television creates familiarity and influences children's ideas of places. The importance of familiarity was also seen in the study by Barca and Pinto (2005), who suggested that one way that children make sense of historic places is in the light of personal experience. This idea was further confirmed in this study, where the children made personal associations with sites, either associating the sites with previous visits they had personally made to them, or imagining themselves at the sites. It also compliments what Tilden (2007) writes about the children identifying themselves with a scene. All of this highlights the importance of what is already known and familiar to children in informing how they understand heritage. Of particular importance, in terms of drawing lessons for practitioners, is the manner in which children's impressions of heritage sites seem to draw on stereotypical connotations, as for example (in phase 1), one child's assumption that Paris is 'supposed to be romantic'. In the findings from phase 3, stereotypes re-emerged, as discussions with the children 
implied that they seem to make very clear distinctions between the kinds of places that they visit, labeling some as 'educational' places and others as not educational.

The influence of television may also explain the evident attraction of the audio-visual aspects of the exhibition in the visitor centre. It may be that as well as being highly influential in forming their images of heritage sites, television may be central in explaining why certain aspects of a site are more enjoyable than others. This in turn suggests an interest in drama, like that which is found in the audiovisual, and which would be also found in the television programmes that they watch. As suggested by much of the literature (Kadlec, 2009), imagination played a large part in the children's experiences. This was especially seen in how the children enjoyed imagining what it would be like to be a soldier. This corresponds to what Kadlec (2009) writes about imagination playing such an important part in children's learning experiences. The notion of imagination in younger visitors may also be linked with their appreciation of the dramatic aspects of the visit. Thus, the findings suggest that the way in which this group of children makes sense of heritage is multi-faceted. The initial encounter seems to be negotiated

along lines of familiarity and even once engaged in the activity of experiencing different elements of the site, it may be the sense of familiarity that enables them to relax and actively appreciate the site (as opposed to feeling alienated by it). However, once at ease and engaged with the site it seems that playfulness and imagination become very important avenues through which the children negotiate and make sense of the sensory experiences on offer.

\subsection{Meanings}

Discussions in phase 3 found that the audio-visual part of the exhibition was the most favoured, or one of the most favoured parts for 21 of the 34 children studied. The laser display and the weapons, were the other favourite parts. The technology involved in the multimedia displays strongly appealed to the children, as seen from their interest in the laser display and audio-visual, and especially seen in one child's interest in the functioning of the laser projectors. Durbin (2002) noted the increased interest by a visitor when multimedia is used, and this has been further confirmed by this study. The children's accurate memories of the laser display also indicate that they were particularly attentive during this part of the visit. It was apparent from the findings that children were more likely to remember elements of the site if they had some sort of visual record of it. For example, they were more likely to remember the Guide's descriptions if visual aids or gestures had been used. This suggests the need for guided tours in general to incorporate visual aids, and the potential of using gestures and other body language to hold the attention of the children. Children's tours may require more consideration of the performance aspect of guided tours 
than adults' tours do, again suggesting the importance of drama to children.

The children seemed particularly interested in the uniforms worn by the soldiers. The drawings gathered from the children after the site visit made this very clear. Most of them included accurate representations of how the soldiers looked, including fine detail. This interest in the details of the clothes of the soldiers may also be due to what Cullingford (1995) refers to as the 'curiosity in cultural differences of even the smallest detail'. Their inclusion of the field signs on the hats, etc., in their drawings signifies their interest in such small detail. The interest in detail can also be seen in how the children thought the audio-visual explained the battle better than the laser display, mainly because of its portrayal of the people, as discussed in phase three. In this way, they enjoyed considering the experience of individual soldiers, rather than the overall story of the battle (which would have been explained in the laser display). This again, suggests the tendency for children to notice detail rather than the over-arching story of the site/event. Tilden (2007) also recognised this tendency.

\section{Please insert Figure 3 about here}

In general, it tended to be the active, participative parts of the visit that stood out most for the children. While they enjoyed their trip to the Battle of the Boyne site, with one child noting 'it's the best so far, of the educational ones it's the best so far', it did not surpass an outdoor adventure park they had previously visited. It seemed that heritage sites with educational connotations, those, according to one child, that 'have information panels and if you're learning stuff', are inherently less attractive. This echoes Small's (2008) findings regarding children and their memories of holidays, and Black's (2001) remarks on children and activities at heritage sites. It was clear from observing the children during the visit that completing the quiz was very popular. It was an opportunity for them to actively participate, in contrast to other parts of their visit which were more passive. Participating in the quiz may have also resulted in the children being 'mindful' during this part of the visit, and therefore more satisfied with it than some other parts (Moscardo, 1996).

The fact that the children completed the quiz in groups of five or six may also have contributed to their enjoyment of this activity, considering the importance noted in previous research (Larsen and Jenssen, 2004; Small, 2008) of socialising in making holiday and school trips enjoyable for children. Likewise, the children studied here indicated in phase one that their favourite thing about school trips was being with their friends. They expressed dissatisfaction with previous visits where they were not allowed to talk to each other. Thus the social aspect of working in a group to find answers to the quiz may have been a factor. Another social aspect of children's experiences of heritage sites is their interaction with the Guides working at the sites. This is a social aspect which is less discussed in literature. The findings of 
this study indicate that the nature of the Tour Guide - children interaction has a significant effect on children's experience and memories of visiting heritage sites. This was first seen in their memories, in phase one, of one past school trip being centred around a Guide who they did not like. The importance of children liking their Guide is seen in the ideas of Tilden (2007) who writes that Guides should conceal direct instruction, so as to develop a sense of companionship with the children. This conveys an example of the type of things Guides could keep in mind, so as not to appear that they are 'giving out' (as the children accused their previous Guide of doing). This sense of respect and trust between Guide and children is therefore crucial to maintain before the children can begin to enjoy and learn from the guided tour experience.

As well as children enjoying social aspects of visiting, their understanding of a place is affected by who they are with. This point was strongly argued by the expert interviewees and was borne out in the findings more generally. Children were noticeably attentive during the guided tour part of their visit and in discussions afterwards it was clear that they had appreciated having a Guide. When asked if they would have preferred having no Guide at all, they said no, with some explaining 'you wouldn't know anything' and 'it helps you to understand'. While the children remembered parts of the exhibition that the Guide had not pointed out to them, they seemed to have particularly strong visual memories of things that the Guide had pointed out to them such as 'the cannonball over the door' and 'the big spear thing'. They also remembered various processes that the Guide had described using lots of gestures, for example, the description of the musket loading drill: 'he had to bite the bullet and put it in'. Interestingly, some children noted in phase one that they would appreciate Guides who can make them laugh. This aspect of humour is something which appears to be particularly important to most of the children, and was further confirmed by their inclusion of humour in many of their drawings in phase two. The importance of humour for children could also be seen simply in the fact that much of the discussion with them throughout the fieldwork for the study (both in phase one and two) involved laughter. While inclusion of humour in heritage site interpretation is something which would need to be carefully managed, it appears that it could have a strong effect on the children's experience. This is not something which has been discussed in previous research on the subject.

Barca and Pinto (2005), in discussing how children make sense of historic streets, highlighted children's capacity for creative and personal reflection. This was highlighted also in this study, during a discussion on the relative importance of natural and cultural heritage sites. The children expressed diverse opinions and argued intelligently, suggesting their capability of considering and debating such issues. 


\section{CONCLUSION}

This paper has endeavoured to shed light on how a group of 34 children aged 11-12 years make sense of a school trip to a heritage site. Through working directly with children, the study has generated some exploratory insights into the more general topic of how children make sense of heritage sites, a research topic that has excited little interest in the literature to date, and as such this study has begun to fill a major gap in previous research. The study has investigated the school group's perceptions of heritage, what aspects of heritage appeal to them, and what impression the heritage experience has on them. In general, its findings tend to support extant knowledge on children and heritage, and go some way to furthering our knowledge of it.

The findings confirmed that children's ideas about destinations can be similar to their ideas of heritage sites. The children studied in this research understand and appreciate heritage sites based on their knowledge of other places, which means that their preconceptions of a site are informed by their perceptions of the host city/country, which in turn may be informed by television. Their enjoyment of the heritage site studied here was found to be relative to other places they were accustomed to visiting, (like adventure parks), and was affected by how familiar or new it seemed to them. In terms of experiencing heritage sites, the study indicated the importance of providing opportunities for interaction and for visual aids to allow children to facilitate a style of learning that is similar to learning through play. While this point has already been made in the literature to some extent, the findings here strongly suggest that such aspects allow imagination and role-playing to flourish, and these are key avenues of learning for children.

Another interesting aspect dealt with in this study has been the interest of children in technology at heritage sites. This has not been previously studied to any great extent, and considering the increasing developments in technology, this is an aspect of interpretation which merits further investigation. In

particular, future research could consider whether technology may in some cases distract from the material being interpreted, as this study indicated that the children sometimes seemed more fascinated with technology itself rather than with the content.

The study suggested the importance of social aspects in shaping children's experiences of heritage, including the importance of the relationship formed between the Tour Guide and the children. With the exception of Tilden's (2007) work, this relationship has been little studied to date. Here it was clear that the way in which the Guide interacted with the children mattered, with the latter preferring Guides to be animated and positive in their interactions. The fact that the children were accompanied by their school friends was also important and added to their enjoyment of the site. These findings on the role of socialising contribute to the limited knowledge that exists on school trip-taking, a tourism practice that is 
distinctly under-researched (Ritchie et al, 2003). However, while they support Larsen and Jenssen (2004) in noting the importance of socialising as a motivation to go on school trips it also found that this group of children place significant importance on the destination of school trips.

Although this has been an exploratory study, the lack of previous research on this topic means that the findings here can contribute in a variety of ways to the literature on heritage site policy and management. In general, it was found that offering interpretation using a variety of multimedia in addition to a guided tour resulted in an enjoyable and memorable visit for the children studied here. The quality of the relationship with the Tour Guide was identified as being particularly important not simply because of the nature of the narrative content provided but because of the tone and approach adopted towards the children. In both of these senses, heritage sites open to children could benefit from tailoring guided tours for young groups. For example, humour could be included in tours. There was evidence that tours for children also need to focus on the detail of the story, rather than on the overall story. One way to deal with this may be to consider the story of the site from one historical character's point of view and present it to the children in this way. This would encourage imagination, another aspect which was found to be extremely important in their visit. As well as this, tours for children may need to focus more on the performance aspect of the presentation than those for adults. This involves incorporating elements of drama, and perhaps more visual props. The inclusion of activity, such as a quiz, was also found to contribute to children's engagement with the heritage experience. As it has been shown that children's experiences are shaped by those who accompany them, it seems appropriate that visitor centres and heritage sites should provide specific information for families, and other young visitors who do not receive guided tours. In this context, a fruitful avenue for further study could involve researching families rather than school classes, in order to learn more about how the experiences at issue compare.

The fact that this study involved working directly with children was in itself unusual. The innovative methods used contribute to existing methodologies. The phased approach was found to be particularly successful, as it allowed the author a good understanding of the children, and for the children to develop a sense of trust in the author. The combination of data collection tools allowed for a large amount of data to be collected, and allowed the children to communicate their ideas in different ways. This methodology has provided a template which could be adapted to other similar qualitative studies with children.

The nature of this study has been exploratory, exploring just one group of children and one heritage site, but its conclusions may serve as an introduction to the many fruitful possibilities that exist for probing further into the area. Children make up a significant portion of visitors to heritage sites, both 
through school tourism and otherwise. While they undoubtedly represent a future generation of adults who will hold responsibility for the preservation and management of such heritage, the study of this group of primary school children has suggested that children make up a distinctive cohort which engages with heritage in a variety of intelligent, curious and valid ways. Heritage sites provide children with very valuable social, cultural and educational experiences. For all of these reasons, enhancing our understanding of how children make sense of heritage and of how heritage sites in turn may seek to render themselves more engaging for children, seems a very valuable endeavour. By investigating such concepts as familiarity, technology, imagination, activity, humour and drama, heritage providers can ensure that children's experiences of such places are at once engaging, enjoyable and enlightening.

\section{References}

Barca, I. \& Pinto, H. (2003). How children make sense of historic streets: Walking Through Downtown Guimarães. International Journal of Historical Learning, teaching and Research, 3 (2), pp. 2 - 9.

Barker, J. \& Smith, F. (2001). Power, Positionality and Practicality: Carry out fieldwork with children. Ethic, Place, and Environment, 4 (2), pp.142-147.

Berg, B. L. (2009). Qualitative Research Methods: For the Social Sciences (7th ed.), Boston: Pearson International Edition.

Black, G. (2001). What, whys, and whos of concept design. In S. Drummond \& I. Yeoman (Eds) Quality Issues in Heritage Visitor Attractions, (pp. 100-120). Oxford: Butterworth-Heinemann.

Bundy, P. (2005). Asking the Right Questions: Accessing Children's Experience of Aesthetic Engagement, Applied Theatre Researcher, 6 (12). Accessed from: http://www.griffith.edu.au/_data/assets/pdf_file/0011/54938/asking-right-question.pdf [30 ${ }^{\text {th }}$ May 2011].

Burnett, K. A. (2001). Heritage, authenticity and history. In S. Drummond \& I. Yeoman (Eds) Quality Issues in Heritage Visitor Attractions, (pp.39-53). Oxford: Butterworth-Heinemann.

Carr, N. (2011). Children's and Families Holiday Experiences, London and New York: Routledge.

Cullingford, C. (1995). Children's Attitudes to Holidays Overseas. Tourism Management, 16 (2), 121-127.

Dahles, H. (2002). The Politics of Tour Guiding: Image Management in Indonesia. Annals of Tourism 
Research, 29 (3), 783-800.

Dunkley, R., Morgan, N. \& Westwood, S. (2011). Visiting the trenches: exploring meanings and motivations in battlefield tourism. Tourism Management, 32(4): 860-868.

Durbin, G. (2002). 'Interactive Learning in Museums of Art and Design', paper presented at Interactive Learning in the British Galleries: 1500-1900, London, 17-18 May. Available from: http://media.vam.ac.uk/media/documents/legacy_documents/file_upload/5752_file.pdf [20th April 2011].

European Commission (2008). Access of Young People to Culture, Interarts, Mallorca. Available from: http://www.epractice.eu/files/Access\%20of\%20Young\%20People\%20to\%20Culture\%20\%20Final\%20Report.pdf [5th December].

Frost, W. \& Laing, J. (2013). Commemorative Events. Memory, Identities and Conflict. Oxon: Routledge.

Graburn, N. (1983). Editor's page, Annals of Tourism Research, 10, 1-5.

Isaksen, K. J. \& Roper, S. (2010). Research with children and schools: A researcher's recipe for successful access. International Journal of Market Research, 52 (3), pp.303-318.

Kadlec, A. (2009). Play and Public Life. National Civic Review, 98 (4), 3-11.

Kelly, L. (2000). Writing text and labels: A review of the literature. Accessed from: http://australianmuseum.net.au/Writing-Text-and-Labels [20th April 2011].

Kerr, M.M. and Price, R.H. (2016) Overlooked encounters: young tourists' experiences at dark sites. Journal of Heritage Tourism, 11(2): 177-185.

Kids in Museums (2011). Kids in Museums Manifesto. Accessed from: http://www.keepandshare.com/doc/2516424/kim-manifesto-layout-2011-1-pdf-january-13-2011-9-14-pm779k?da=y [21st April 2011].

Larsen, S. \& Jenssen, D. (2004). The school trip: Travelling with, not to or from. Scandinavian Journal of Hospitality and Tourism, 4 (1), 43-56.

MacAuley, C. (1996). Children in Long term Foster Care: Emotional and Social Development, Hampshire: Avebury. In: Barter, C. \& Renold, E. (2000). 'I wanna tell you a story': exploring the 
application of vignettes in qualitative research with children and young people. International Journal of Social Research Methodology, 3 (4), pp. 307-323.

Madrigal, R. (1993). Parents' perceptions of family members' relative influence in vacation decisionmaking. Journal of Travel and Tourism Marketing, 2 (4), 39-58.

Moscardo, G. (1996). Mindful visitors: heritage and tourism. Annals of Tourism Research, 23 (2), 376-397.

Munday, V. (2002). Guidelines for Establishing, Managing and Using Handling Collections and Hands on Exhibits in Museums, Galleries and Children's Centres. Accessed from: http://www.mla.gov.uk/what/publications/ /media/Files/pdf/2002/handling_collections.ashx [20th April 2011].

Nickerson, N. and Jurowski, C. (2001). The influence of children on vacation travel patterns. Journal of Vacation Marketing, 7 (1), 19-30.

Obrador, P. (2012). The place of the family in tourism research: Domesticity and thick sociality by the pool. Annals of Tourism Research, 39 (1), 401-420.

Poria, Y. and Timothy, D.J. (2014) Where are the children in tourism research? Annals of Tourism Research, 47: 93-95.

Poria, Y., Butler, R., \& Airey, D. (2003). The core of heritage tourism. Annals of Tourism Research, 30 (1), 238-254.

Ritchie, B.; Carr, N. and Cooper, C. (2003). Schools' educational tourism. In B. Ritchie with N. Carr and C. Cooper, Managing Educational Tourism (pp. 130-80). Clevedon: Channel View Publications.

Ryan, C. (2007). Battlefield Tourism: History, Place and Interpretation. Oxford: Elsevier.

Saunders, M., Lewis, P. \& Thornhill, A. (2007). Research Methods for Business Students (4 ${ }^{\text {th }}$ ed.), Essex: Pearson Education Limited.

Schanzel, H., (2012). 'The inclusion of fathers, children and the whole family group in tourism research on families'. In H. Schanzel, I. Yeoman, \& E. Backer (eds) Family tourism: Multidisciplinary perspectives, Bristol: Channel View Publications, pp.67-80.

Schanzel, H., Yeoman, I. \& E. Backer (eds) (2012). Family tourism: Multidisciplinary perspectives, Bristol: Channel View Publications. 
Schorch, P. (2012). Cultural feelings and the making of meaning. International Journal of Heritage Studies, pp. $1-14$.

Small, J. (2008). An absence of childhood in tourism studies. Annals of Tourism Research, 35 (3), $772-$ 789.

Tabraham, C. (2006). Interpreting Historic Scotland. In A. Hems \& M. Blockley (Eds) Heritage Interpretation (pp. 55-70). London: Routledge.

Taylor, R. (2006). The National Trust. In A. Hems \& M. Blockley (Eds) Heritage Interpretation (pp.97110). London: Routledge.

Thornton, P. R., Shaw, G. and Williams, A. M. (1997). Tourist group holiday decision-making and behavior: the influence of children. Tourism Management, 18 (5), 287-297.

Tilden, F. (2007). Interpreting our heritage (5th ed.) Chapel Hill: University of North Carolina.

Urry, J. (1990). The Tourist Gaze. Leisure and Travel in Contemporary Societies. London: Sage Publications Ltd.

Wang, K., Hsieh, A., Yeh, Y. \& Tsai, C. (2004). Who is the decision-maker: The parents or the child in group package tours? Tourism Management, 25 (2), 183-194.

Wendling, R. C. (1989). Outdoor Education for Rural Fifth Graders: Analysis of Attitudes, 100 expectations, Knowledge and Perceptions. In D. L. Uzzell, (Ed.) Heritage Interpretation, Volume 2: The Visitor Experience ( pp.166-178). London: Belhaven Press,

WHC UNESCO (2010), World Heritage Education, UNESCO. Available from: http://whc.unesco.org/en/wheducation [5th December 2010]. 
Table 1: Data Collection Phases

\begin{tabular}{|c|c|c|}
\hline 1. Classroom & 2. Heritage site visit & 3. Classroom \\
\hline $\begin{array}{l}\text { - Written comments } \\
\text { about pictures of } \\
\text { heritage sites } \\
\text { - Group Discussion } \\
\text { - Topics covered: } \\
\text { heritage sites in } \\
\text { general, the Battle of } \\
\text { the Boyne Visitor } \\
\text { Centre, previous } \\
\text { school trips, and } \\
\text { expectations of the } \\
\text { next day's visit }\end{array}$ & $\begin{array}{l}\text { - } \text { Guided tour } \\
\text { - } \quad \text { Quiz } \\
\text { - } \begin{array}{l}\text { Task: written piece and } \\
\text { drawing }\end{array} \\
\text { - Observation of all by } \\
\text { the researcher }\end{array}$ & $\begin{array}{l}\text { - } \text { Group Discussion } \\
\text { - Topics covered: the } \\
\text { previous day's trip; } \\
\text { comparison of that trip } \\
\text { with trips to other } \\
\text { similar places or to } \\
\text { places on holiday; and } \\
\text { a comparison of the } \\
\text { visit with schoolwork }\end{array}$ \\
\hline
\end{tabular}




\section{Figure Captions:}

Figure 1. A drawing depicting humorous speech bubbles.

Figure 2. A drawing depicting the projectors used in the laser display.

Figure 3. A drawing displaying soldiers with 'field signs' in their hats. 